\title{
THE DISTRIBUTION OF COPPER IN SARONICOS GULF AFTER THE OPERATION OF THE WASTEWATER TREATMENT PLANT OF PSITALIA
}

\author{
M. DASSENAKIS* \\ M. SCOULLOS \\ K. RAPTI \\ A. PAVLIDOU \\ D. TSOROVA \\ V. PARASKEVOPOULOU \\ E. ROZI

\section{A. STAMATELI} \\ M. SIGANOS
}

Selected from papers presented at the $8^{\text {th }}$ Conference on Environmental Science and Technology,

8-10 September 2003, Lemnos, Greece.

\author{
University of Athens, Department of Chemistry \\ Section III, Laboratory of Environmental Chemistry \\ Panepistimioupoli Zografou, 15771 \\ Athens, Greece
}

*to whom all correspondence should be addressed:

tel/fax: +(30)-210-7274269

e-mail: edasenak@cc.uoa.gr

\begin{abstract}
The establishment of the Wastewater Treatment Plant of Athens is considered as the main factor contributing to the improvement of water quality and recovery of the marine ecosystem in Saronicos gulf as it removes significant percentage of pollutants entering the gulf, including heavy metals.

The comparison of concentrations of dissolved and particulate copper during 1993, 1994 (before the operation of the plant) and 1998, 1999 and 2000 (after the beginning of the operation) revealed that some changes in the distribution of copper occurred because of this major change concerning the pollution sources of the gulf.

The effects are both direct, like the increased concentrations in the sediments near Psitalia and the slight decrease of mean values of dissolved copper and indirect, associated with the decrease of dissolved oxygen in the deep water of the western basin, i.e. the decrease of dissolved copper in this layer and the increase of copper concentrations in surface sediments.

The general conclusion of this study is that the overall picture of copper pollution of the gulf has differentiated but not radically changed.
\end{abstract}

KEYWORDS: Copper, Seawater, Sediment, Saronicos

INTRODUCTION

In the present study we investigated the influence of the Wastewater Treatment Plant of Psitalia on the distribution and chemical behaviour of copper 
in Saronicos gulf. For this purpose we have chosen to compare concentrations of dissolved and particulate copper before the start of operation of the treatment plant (1993-1994) and after a few years (1998-2000). We also analysed sediment cores received in the year 2000.

Saronicos gulf, in the vicinity of Athens, is considered to be among the most polluted Greek gulfs. The area of the gulf is about $2600 \mathrm{~km}^{2}$ and the maximum depth is $450 \mathrm{~m}$. About $40 \%$ of the country's industries are located on the coast of Attiki, along the northern part of the gulf. Some large industries (oil refineries, shipyards, chemical plants, food, metal, cement industries etc.) are located within the Elefsis gulf. Navigation and shipping related activities are additional sources of pollution, since Piraeus harbour is one of the main Mediterranean ports.

Until 1995 the effluents of Athens (more than $6 \times 10^{5} \mathrm{~m}^{3} \mathrm{~d}^{-1}$ ) were discharged, untreated, in the shallow waters of Keratsini bay through the Central Sewage Outfall. The operation of the Wastewater Treatment Plant of Athens began by the end of 1995. The treatment plant was built on Psitalia Island (a historical small island between Salamis and the coast of Attiki). The plant, until this day, includes primary treatment of the effluents in deposition tanks, for the removal of suspended solids and part of the organic load, and treatment of the resulting sewage sludge before discharge to a sanitary landfill. The treated effluents are discharged near bottom (60 m depth) through two pipes at a distance of about $1.9 \mathrm{~km}$ from the coast. Measurements of the effluent quality have revealed that the system removes about $60 \%$ of the suspended solids and $34 \%$ of organic matter. The average daily flow is $638 \times 10^{3}$ $\mathrm{m}^{3} \mathrm{~d}^{-1}$ and the average hourly flow $29.8 \times 10^{3} \mathrm{~m}^{3} \mathrm{~h}^{-1}$. The maximum total polluting load is on February and the minimum on August. (Vilioti and Dassenakis, 1999). The mean removal of copper from the effluents after primary treatment at the plant has been measured to be about $45 \%$ (Firfilionis, 2003). A secondary treatment plant is nearly under completion, for further reduction of the polluting load discharged to the gulf.

The marine environment of Saronicos gulf is monitored since 1986, in the framework of the MED-POL/ UNEP National Monitoring Project (Dassenakis et al., 2001). The results of this on going project indicate that Elefsis gulf is the most polluted part of Saronicos. Intermittently anoxic conditions are developed every summer in Elefsis gulf below $15 \mathrm{~m}$, due to the intense stratification of the water column. This phenomenon occurs every summer regardless of the pollution of the gulf (Scoullos and Riley, 1978).

The adequate renewal of water masses in the eastern part of the gulf has prevented the appearance of significant ecological degradation. On the contrary, in the western part of the gulf (which is deeper and less affected by polluting activities) the renewal of water is very slow. In the last few years and after the establishment of the treatment plant, a permanent decrease of dissolved oxygen is observed in the deeper layer (under $100 \mathrm{~m}$ ) of the western basin (Psilidou et al., 1997). The effluents of the treatment plant, transported there through near bottom currents, may be responsible for this phenomenon.

Copper is widely distributed in nature and it is one of the main trace elements from an environmental point of view. It is used primarily in electrical, construction and piping industries and also has important pharmaceutical and agricultural uses. Copper is highly toxic to most aquatic organisms in relatively low concentrations. In the Mediterranean region, an important source of copper to the coastal marine environment is its use as a fungicide in vineyards. Following the restrictions in the use of antifouling paints containing TBTs, the use of copper based paints has increased (UNEP, 1993). Levels of dissolved and particulate copper in Saronicos gulf, the Aegean Sea and the Open Mediterranean are given in Table 1.

\section{METHODS}

Seawater samples were collected seasonally (4 times per year, 40 samples per sampling) with polypropylene sampling bottles and were filtered through preweighed $0.45 \mu \mathrm{m}$ Millipore membrane filters for the collection of particulate matter. The filters were treated with boiled concentrated $\mathrm{HNO}_{3}$ in Teflon screw capped beakers. Dissolved copper was determined after preconcentration with Chelex-100 resin columns (Riley and Taylor, 1968; Scoullos and Dassenakis, 1984). Standard addition experiments have shown that the recovery of $\mathrm{Cu}$ is about $95 \%$ (Rapti, 2000). A Varian 640-Z Graphite Furnace A.A.S. with background correction based on the Zeeman 
Table 1. Comparative concentrations of dissolved and particulate copper

(Dassenakis et al., 2000; Zeri and Voutsinou, 2003)

\begin{tabular}{|c|c|c|}
\hline Area & Dissolved copper $\left(\mu \mathrm{g} \mathrm{l}^{-1}\right)$ & Particulate copper $\left(\mu \mathrm{g} \mathrm{l}^{-1}\right)$ \\
\hline \multicolumn{3}{|c|}{ Saronicos gulf (1986-1993) } \\
\hline Mean & 1.25 & 0.27 \\
\hline Range & $0.10-10.7$ & $0.02-2.11$ \\
\hline \multicolumn{3}{|c|}{ North Aegean Sea (1997-1998) } \\
\hline Mean & 0.9 & - \\
\hline \multicolumn{3}{|c|}{ Open Mediterranean (1990) } \\
\hline Range & $0.10-0.40$ & - \\
\hline
\end{tabular}

Effect was employed for the analysis.

Small sediment cores (about $20 \mathrm{~cm}$ ) were collected in February 2000, with a box corer and divided in parts of $5 \mathrm{~cm}$ each. The sediment samples were wet sieved through nylon net with openings of $61 \mu \mathrm{m}$ for separation in two fractions (sand / silt \& clay) and dried at room temperature. Copper was determined in the silt \& clay sediment fraction, which is considered to be the most interesting for trace metal studies. (Forstner and Salomons, 1988; Rabbiti et al., 1983). The total copper content of the sediment was determined after treat- ment with a mixture of $\mathrm{HNO}_{3}-\mathrm{HClO}_{4}-\mathrm{HF}$ in a Pro-Labo 401 microwave apparatus (UNEP, 1985). The extractable fraction of copper was determined after treatment with $0.5 \mathrm{~N} \mathrm{HCl}$ in room temperature (Agemian and Chau, 1976). Copper concentrations were measured with a Varian SpecrtAA-100 Flame A.A.S.

Organic carbon in sediment samples was measured with the method of Gaudette et al., 1974.

Saronicos gulf and the grid of stations are shown in Figure 1. The gulf is subdivided into four sections:

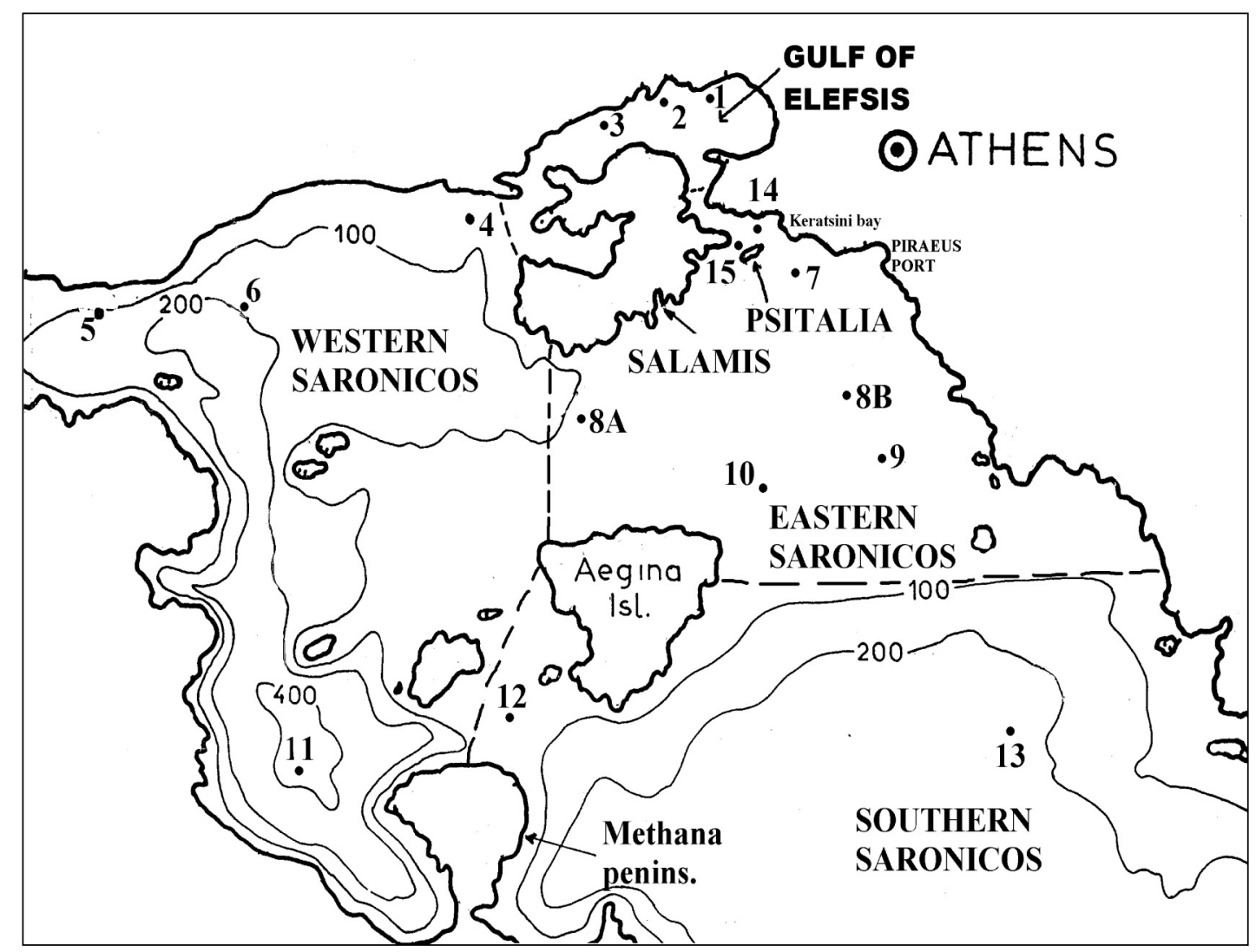

Figure 1: Map of Saronicos Gulf 
1. The South Gulf (external stations 12,13) with maximum depth $200 \mathrm{~m}$,

2. The West Gulf (central stations 4, 5, 6, 11) with depths between $90-400 \mathrm{~m}$,

3. The East Gulf (internal stations 14, 15, 7, 8A, $8 \mathrm{~B}, 9,10)$ with depths up to $100 \mathrm{~m}$,

4. The Elefsis gulf (stations 1, 2,3) with depths up to $30 \mathrm{~m}$.

The most interesting stations for the present study are: 7 (near the exit of the old pipe), 14 (the nearest stations to Psitalia) and 11 (the deepest station).

\section{RESULTS AND DISCUSSION}

\section{Dissolved and particulate copper}

The mean dissolved, particulate and total concentrations of copper as well as the percentage of particulate copper on the total concentration are given in Table 2. Concentrations of copper are given for each sub area of the gulf. The time period chosen for the scope of the present paper is from 1993 until 2000.

A lot of significant seasonal variations of the dissolved copper concentrations have been observed since 1986 (Scoullos et al., 1994), however maxi-

Table 2: Mean Copper concentrations (ppb- $\left.\mu \mathrm{g} \mathrm{l}^{-1}\right)$ for the sub regions of the Gulf

\begin{tabular}{|c|c|c|c|c|}
\hline & Dissolved & Particulate & Total & $\% \mathrm{P} / \mathrm{T}$ \\
\hline & \multicolumn{4}{|c|}{1993} \\
\hline ELEFSIS & 0.88 & 0.19 & 1.07 & 18 \\
\hline WEST & 0.45 & 0.08 & 0.53 & 15 \\
\hline SOUTH & 0.51 & 0.04 & 0.25 & 16 \\
\hline EAST & 0.30 & 0.06 & 0.36 & 17 \\
\hline \multirow[t]{2}{*}{ MEAN } & 0.46 & 0.09 & 0.55 & 17 \\
\hline & \multicolumn{4}{|c|}{1994} \\
\hline ELEFSIS & 2.14 & 0.12 & 2.26 & 5 \\
\hline WEST & 1.32 & 0.04 & 1.36 & 3 \\
\hline SOUTH & 1.24 & 0.05 & 1.29 & 4 \\
\hline EAST & 1.63 & 0.06 & 1.69 & 4 \\
\hline \multirow[t]{2}{*}{ MEAN } & 1.58 & 0.07 & 1.65 & 4 \\
\hline & \multicolumn{4}{|c|}{1998} \\
\hline ELEFSIS & 0.79 & 0.22 & 1.01 & 22 \\
\hline WEST & 0.43 & 0.18 & 0.61 & 30 \\
\hline SOUTH & 0.66 & 0.1 & 0.76 & 13 \\
\hline EAST & 0.27 & 0.14 & 0.41 & 34 \\
\hline \multirow[t]{2}{*}{ MEAN } & 0.54 & 0.16 & 0.70 & 23 \\
\hline & \multicolumn{4}{|c|}{1999} \\
\hline ELEFSIS & 1.37 & 0.24 & 1.61 & 15 \\
\hline WEST & 0.75 & 0.08 & 0.83 & 10 \\
\hline SOUTH & 0.76 & 0.09 & 0.85 & 11 \\
\hline EAST & 0.58 & 0.12 & 0.70 & 17 \\
\hline \multirow[t]{2}{*}{ MEAN } & 0.87 & 0.13 & 1.00 & 13 \\
\hline & \multicolumn{4}{|c|}{2000} \\
\hline ELEFSIS & 0.44 & 0.16 & 0.60 & 27 \\
\hline WEST & 0.16 & 0.06 & 0.22 & 28 \\
\hline SOUTH & 0.09 & 0.04 & 0.13 & 28 \\
\hline EAST & 0.16 & 0.07 & 0.23 & 30 \\
\hline MEAN & 0.21 & 0.08 & 0.29 & 28 \\
\hline
\end{tabular}




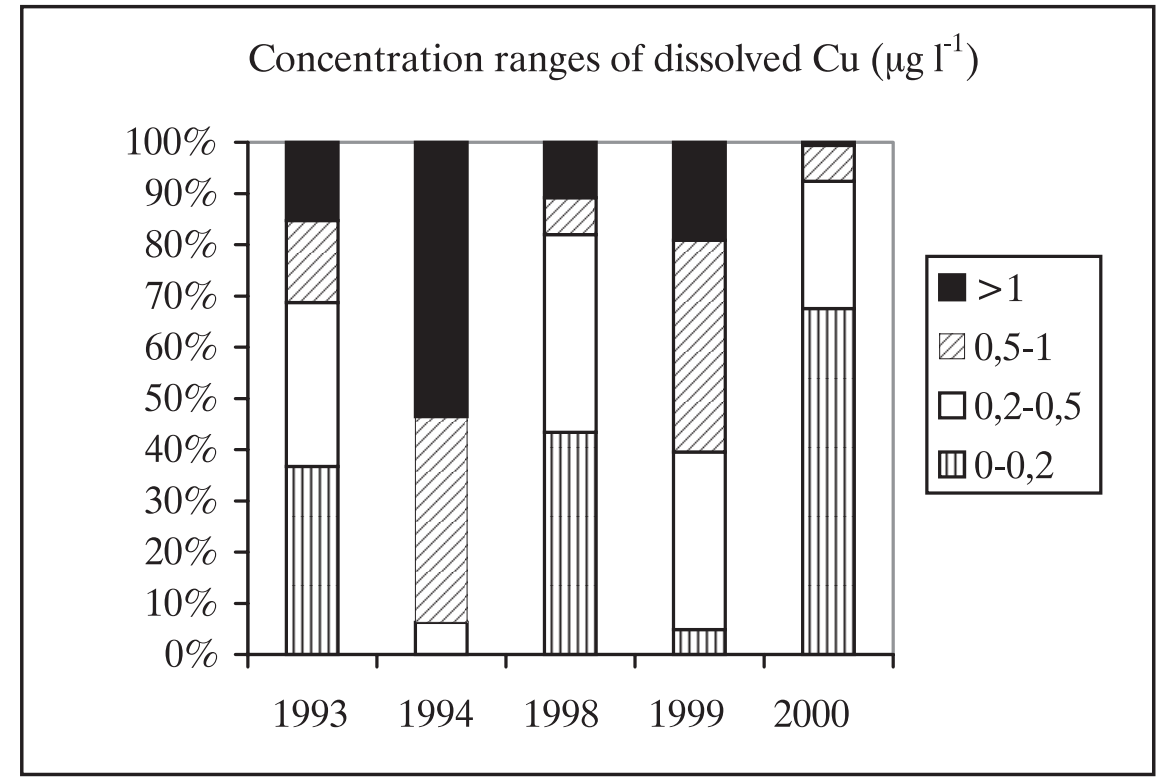

Figure 2: Percentages of values in certain concentration ranges for dissolved copper

mum values were measured during 1994. In all the years the Elefsis gulf was the most enriched part of Saronicos. After 1994 a decreasing trend in the values of dissolved copper was observed. The opposite trend was observed in the case of particulate copper. During 1998-1999 there was an increase in both the concentrations and percentages of particulate copper in comparison to the period of 1993-1994. As in the case of dissolved copper the highest values of particulate copper were observed in the Elefsis gulf (Table 2). The distributions of measurements presented in Figures 2 and 3 reveal that during 1994 there was a substantial increase in dissolved copper levels in the gulf since the percentage of low values was very small. Small percentage of low values was

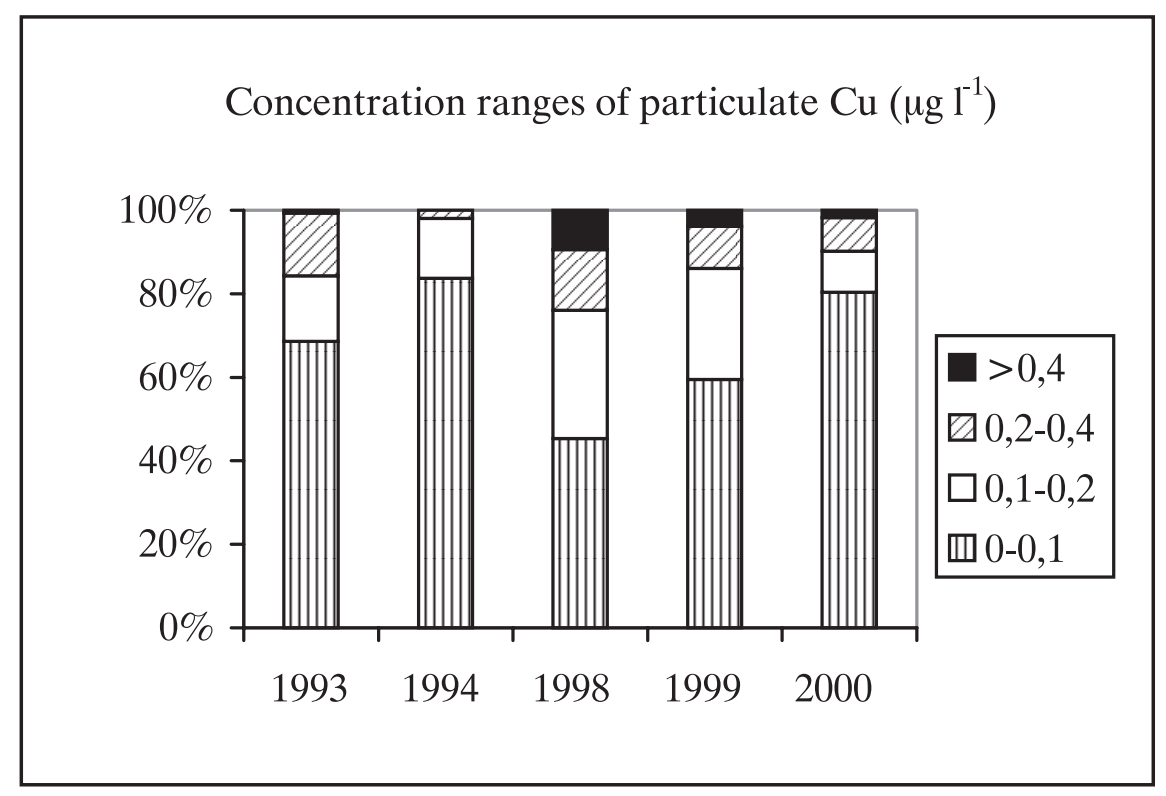

Figure 3: Percentages of values in certain concentration ranges for particulate copper 


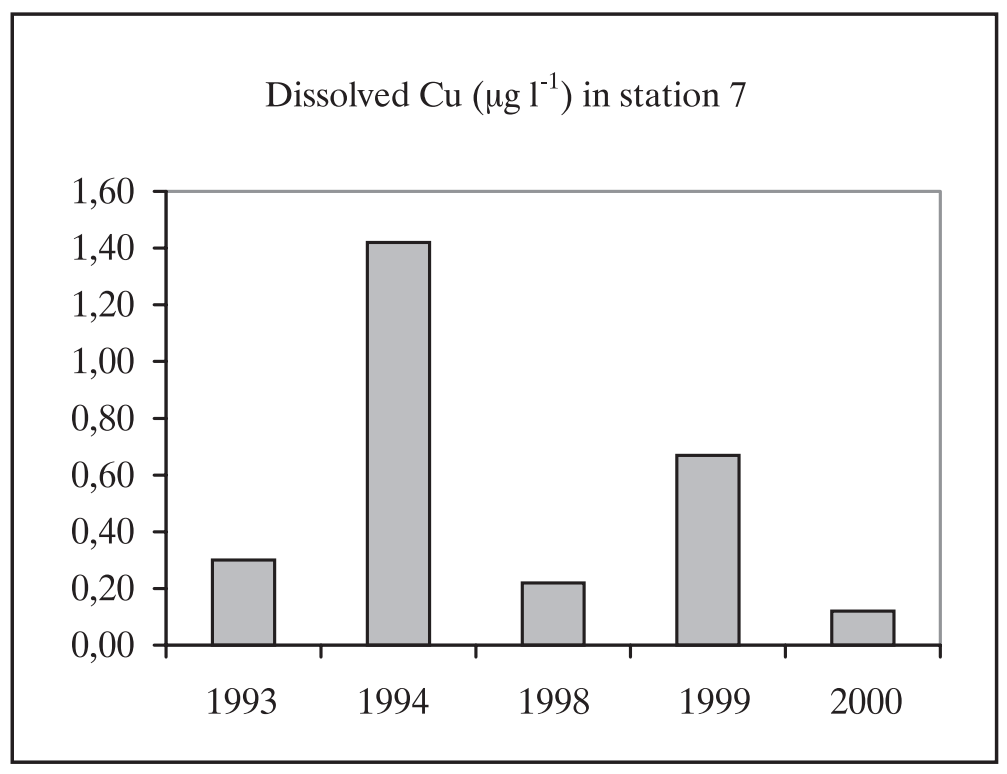

Figure 4: Mean values of dissolved copper for station 7

also observed in 1999, whereas the highest percentage of low values was measured in 2000 . The comparison of 1993 and 1998 indicates similar percentages of high and low values.

For particulate copper the distributions of 1998 and 1999 show a decrease of low values and an increase of the higher ones. This indicates an elevating trend in the pollution of the gulf probably from various sources other than the wastewater treatment plant. The pattern of 2000 is similar to the patterns of 1993 and 1994, with return to lower values. The lack of data for the period between 2001 and 2003 does not allow us to characterize the decreasing trend in the dissolved and particulate copper values of 2000 as permanent.

A similar pattern is observed for the mean concentrations of copper in station 7 near the old Central Sewage Outfall of Akrokeramos in Keratsini bay. The results for station 7 are presented in Figures 4 and 5.

The values of dissolved copper were reduced during 1998-2000 in comparison with 1994.

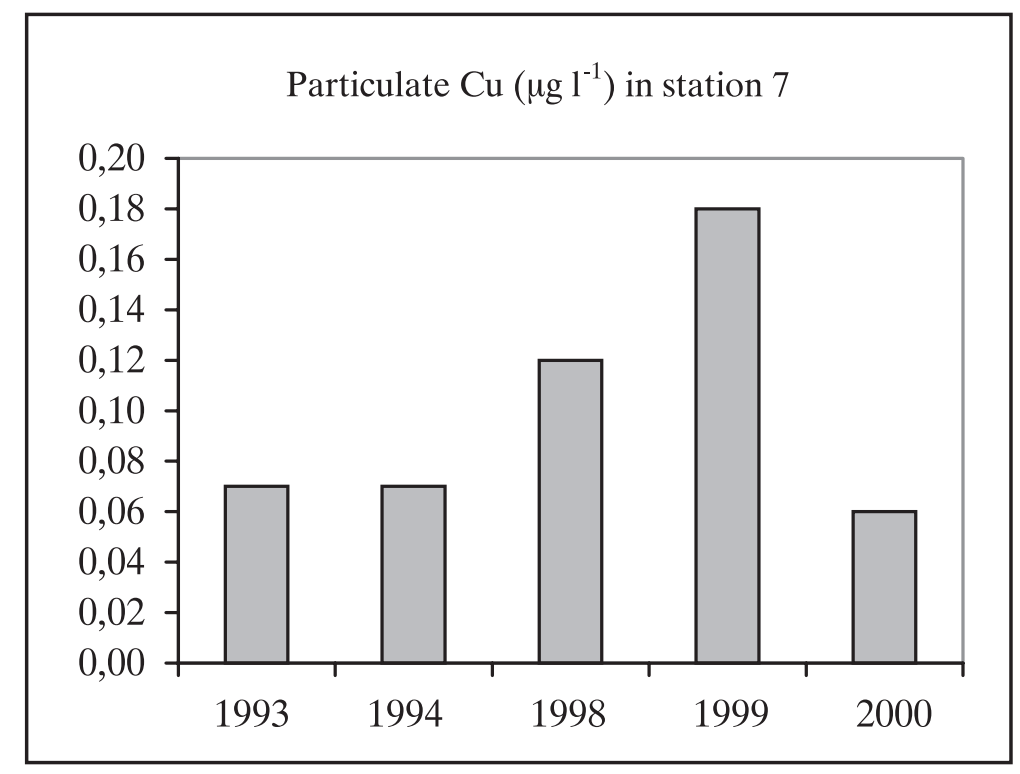

Figure 5: Mean values of dissolved copper for station 7 
In contrast, an increasing trend is observed in the case of particulate copper for 1998-1999 in spite of the lower input from the old outfall. The mean value in 2000 is similar to the values of 1993-1994. Some additional sources of copper in the neighbouring industrial area may be the cause for this observation, which is accompanied by an increase of easily extractable copper in the surface sediment of station 7 (Figure 9).

The mean concentrations of copper in the two
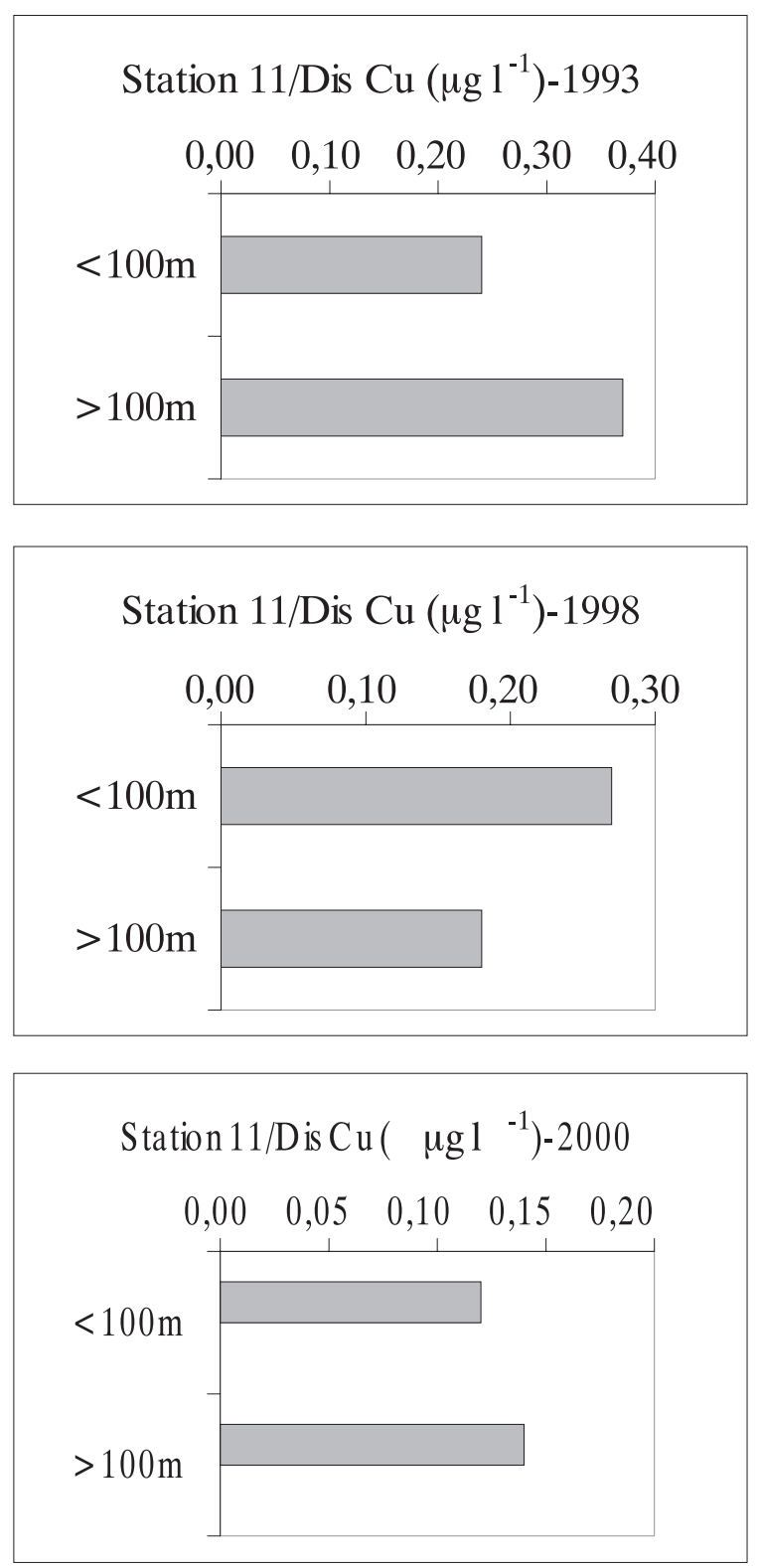

characteristic water layers of the deepest station 11 are compared in Figures 6 and 7. The thermocline there is usually observed between 70 and 90 $\mathrm{m}$. The dissolved oxygen concentration was very low in the deeper layer during 1998 and 1999 (< $2.0 \mathrm{mg} \mathrm{l}^{-1}$ ) (Tsorova, 2000).

Concerning dissolved copper (Figure 6), in 1993 and 1994 higher values were measured below $100 \mathrm{~m}$ probably due to the dissolution of easily extractable copper from the sediments. During
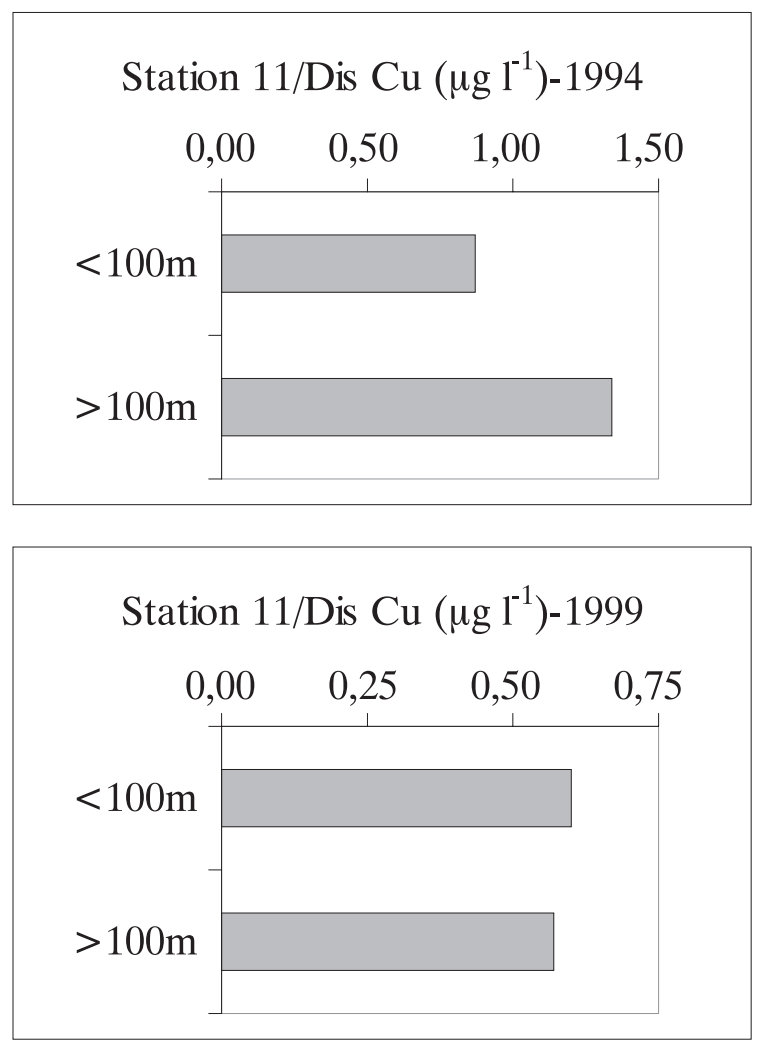

Figure 6: Mean values of dissolved copper (ppb- $\mu \mathrm{g} \mathrm{l}^{-1}$ ) below and over the thermocline for station 11 (Abbreviations: Dis=Dissolved) 
1998 and 1999 the values below 100m were lower, probably because of the existence of hydrogen sulfide, which leads to deposition of $\mathrm{CuS}$. For the same possible reason, deposition to sediments, the concentrations of particulate copper were lower below $100 \mathrm{~m}$ in 1999 and 2000 (Figure 7). This hypothesis is supported by the increased levels of extractable copper in the surface sediments of Station 11 (Figure 9).

The effect of the change of the redox conditions was stronger in the case of manganese due to the formation of soluble $\mathrm{Mn}(\mathrm{II})$ : in 1993 the mean concentration over $100 \mathrm{~m}$ was $0.31 \mathrm{ppb}$ and below
$100 \mathrm{~m}, 0.24 \mathrm{ppb}$ whereas in 1999 the same values were $0.19 \mathrm{ppb}$ and $0.65 \mathrm{ppb}$.

\section{Sediments}

The increased concentration of organic carbon in the upper sediment layer of station 14 reveals the influence from the treatment plant effluents whereas the similar pattern in station 11 indicates that the anoxic conditions decrease the decomposition rate of organic compounds. At station 7 there is a decrease of organic carbon in the upper layer of the sediment core, which indicates the beginning of bioremediation processes in the area (Figure 8).
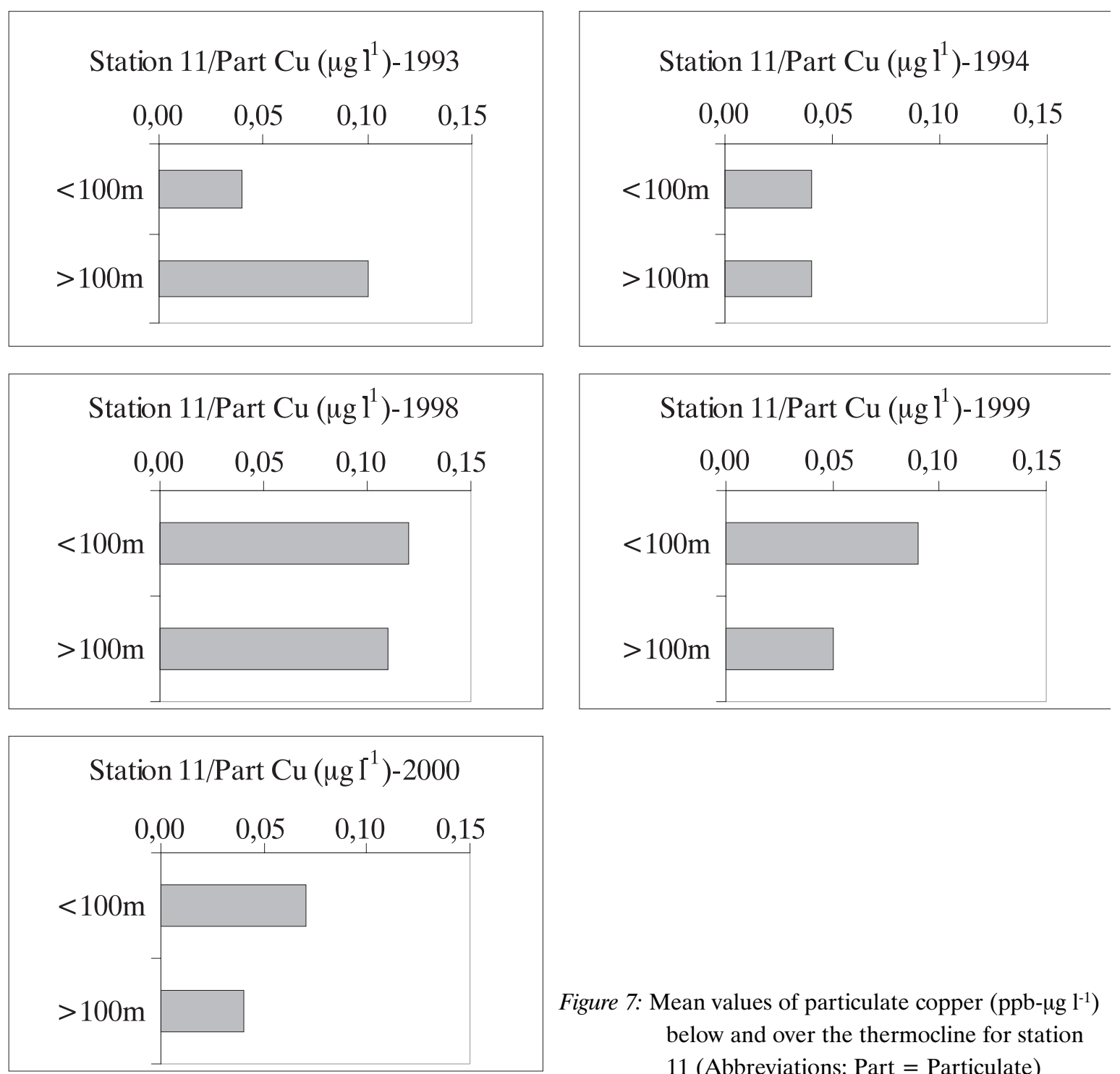

Figure 7: Mean values of particulate copper $\left(\mathrm{ppb}-\mu \mathrm{g}^{-1}\right)$ below and over the thermocline for station 11 (Abbreviations: Part $=$ Particulate) 

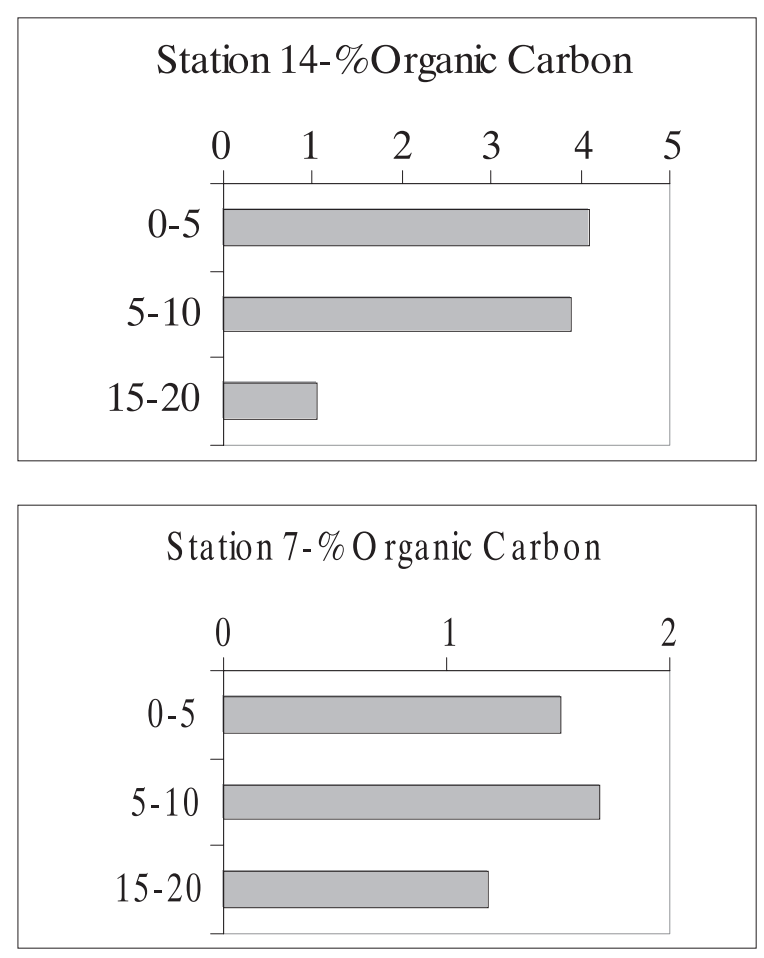

The vertical distributions of copper in sediment cores of stations 7,11 , and 14 that are presented in Figure 9 indicate that the effluents of Psitalia are a significant source of copper and affect the levels of this metal in the sediments of the neighboring areas (station 14).

The significant increase of extractable copper in the upper layer of the sediment in station 11 can be attributed to the almost anoxic conditions that prevail in the area and lead to the deposition of dissolved copper and to increased organic carbon content. There is also the possibility that part of the load from Psitalia is transported to the western part of Saronicos (Tsorova, 2000).

Finally, at station 7 the values of easily extractable copper show that there is input of particulate copper whereas the total concentrations remain similar.

\section{CONCLUSIONS}

The establishment of the Wastewater Treatment Plant of Athens is now considered as the main factor contributing to the recovery of the marine ecosystem and the improvement of water quality in Saronicos gulf.

The effects of the operation of the wastewater

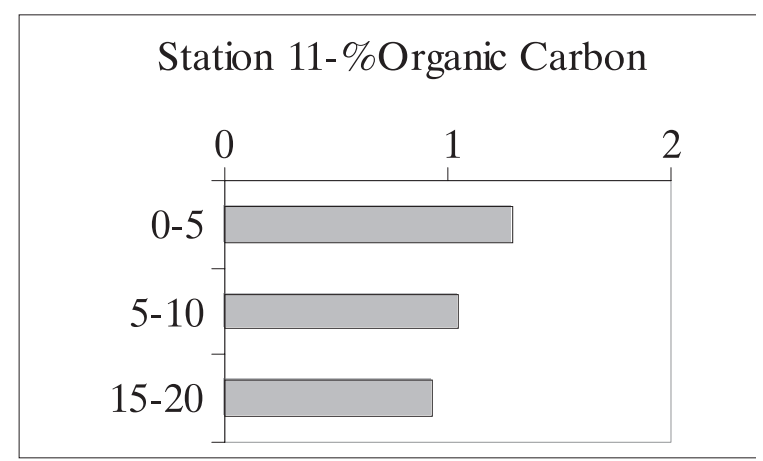

Figure 8: \% Organic carbon in sediment cores

treatment plant on the distribution of copper in Saronicos gulf are of two types:

(a) Direct effects like the increased concentrations in the sediments near Psitalia and the slight decrease of mean values of dissolved copper.

(b) Indirect, associated with the decrease of dissolved oxygen in the deep water of the western basin, i.e. the decrease of dissolved copper in this layer and the increase of copper concentrations in surface sediments.

The general conclusion of this study is that the overall picture of copper pollution of the gulf has differentiated but not radically changed. However the interruption of the MED-POL/ UNEP National Monitoring Project has caused a gap in the time series of trace metal data for Saronicos for the time period 2001-2003. This gap in the data series does not allow us to extract safe conclusions about the influence of the treatment plant in copper distributions. The monitoring of the gulf was recently restarted. This fact will allow us to evaluate the present state of metal pollution in Saronicos and the effect from the impending operation of the secondary wastewater treatment facilities. 


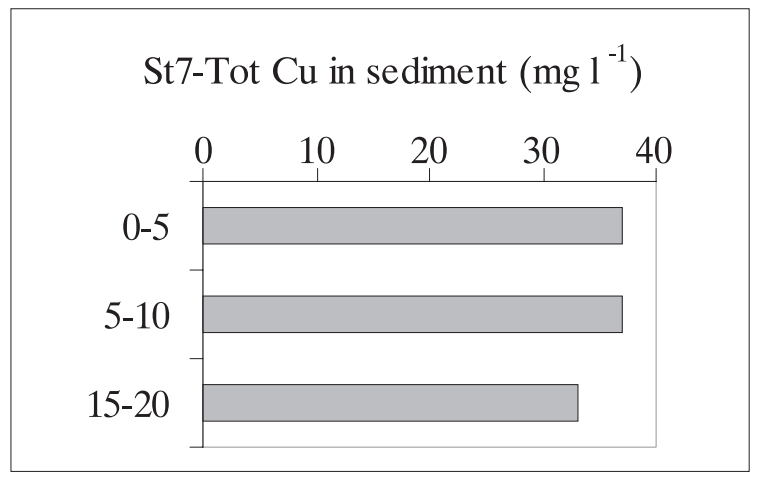

St14-Tot $\mathrm{Cu}$ in sediment $\left(\mathrm{mg} \mathrm{I}^{-1}\right)$

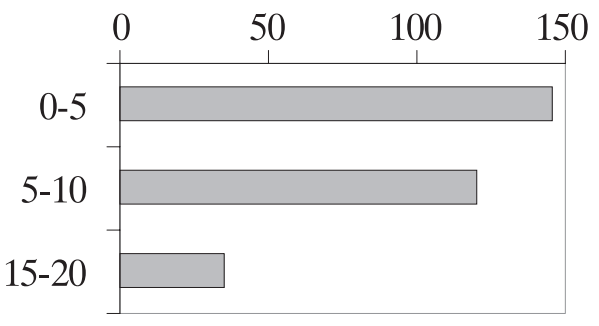

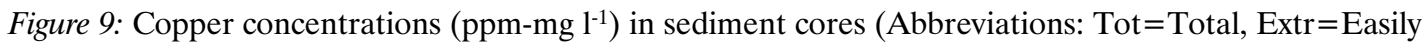
extractable)

\section{REFERENCES}

Agemian F. and Chau A.S.Y., (1976), Evaluation of extraction techniques for the determination of metals in aquatic sediments, Analyst. 101, 761-767.

Dassenakis M., Kapiris K., Pavlidou A., (2000), Chapter 15: The Aegean Sea in 'Seas at the millennium: an environmental evolution' Ed.: Sheppard C., Pergammon, Elsevier Science Ltd.

Dassenakis M., Tsorova D. and Stathopoulou E., (2001), The pollution control in the aquatic environment of Greece, Chemica Chronica, 63 (1), 9-12.

Firfilionis G., Paraskevopoulou G., Vilioti G., Dassenakis M., (2003), The removal of trace metals at the wastewater treatment plant of Psitalia, $7^{\text {th }}$ Hellenic Symposium of Oceanography and Fisheries, Crete 6-9/5/2003, Proceed. 32-33.

Förstner U. and Salomons W., (1988), Trace metals analysis on polluted sediments. I. Assessment of sources and intensities, Envir. Techn. Lett., 1, 494-505.

Gaudette H.E., Flight W., Tones L. and Folger D., (1974), An inexpensive titration method for the determinations of organic carbon in recent sediments, Journal of Sedimentary Petrology, 44, 249-253.

Psilidou A., Paulidou A. and Georgakopoulou E., (1997), Recent measurements of nutrients and dissolved Oxygen in the Saronicos and the Elefsis Gulfs. 5th Symposium in Oceanography, 1, 469.

Rabbiti S., Blodrin A., Menegazzo-Vitturi L., (1983), Relationships between surface area and grain size in bottom sediments', J. Sed. Petrol., 53, 665-667.

Rapti K., (2000), Research for the conditions of the use of the resin Chelex-100 for the recovery and measurement of the trace metals $\mathrm{Mn}, \mathrm{Zn}$ and $\mathrm{Cu}$ in seawater. M.Sc Thesis, University of Athens Dept of Chemistry.

Riley J.P. and Taylor D., (1968), Chelating resins for the concentration of trace elements from seawater and their analytical use in conjunction with A.A.S, Anal. Chim. Acta, 40, 479-484.

Scoullos M and Riley J.P., (1978), Water circulation in the Gulf of Elefsis, Greece, Thalassia Yugoslavica, 14, 357-370. 
Scoullos M. and Dassenakis M., (1984), Determination of dissolved metals in seawater using the resin Chelex-100, Proceeding of the $1^{\text {st }}$ Symposium on Oceanography and fisheries, 302-309.

Scoullos M., Dassenakis M. and Paulidou A., (1994), A brief account on trace metal levels in the Saronicos Gulf, based on the 1986-1993 MED-POL Monitoring Program. International Conference on Restoration and Protection of the Environment II. Proceed. 357-359.

Tsorova D., (2000), Cu, Pb and Ni in Saronicos Gulf during summer 1998. M.Sc Thesis, University of Athens Dept of Chemistry.

UNEP, (1985), Reference Methods for Marine Pollution Studies, No 31-39.

UNEP, (1993), Preliminary assessment of the state of pollution of the Mediterranean Sea by Zinc, Copper and their compounds and proposed measures. UNEP(OCA)/MED/WG.66/Inf.3.

Vilioti G. and Dassenakis M., (1999), Estimation of efficiency of a primary wastewater treatment plant. $2^{\text {nd }}$ Greek Conference on Chemical Engineering, Proceed. 525-528

Zeri C., Voutsinou-Taliadouri F., (2003), Processes affecting the distribution of dissolved trace metals in the North Aegean (Eastern Mediterranean), Continental Shelf Research, 23, 919-934. 